\title{
Kajian Yuridis Pemanfaatan dan Penggunaan Areal Bebas Sempadan Pantai dalam Pembangunan Industri Pariwisata di Kabupaten Lombok Barat Provinsi Nusa Tenggara Barat
}

\author{
Ilham \\ Mahasiswa Program Studi Magister Ilmu Hukum Universitas Mataram \\ Email:imadeindra@gmail.com
}

\begin{abstract}
ABSTRAK
Penelitian ini bertujuan mengkaji hukum pemanfaatan dan penggunaan areal bebas sempadan pantai dalam pembangunan industri pariwisata di Kabupaten Lobar-Provinsi NTB. Isu hukum yang muncul dalam penelitian ini meliputi: bagaiamana pengaturan tentang pemanfaatan dan penggunaan areal bebas sempadan pantai, bagaimana pelaksanaan pemanfaatan dan penggunaan areal bebas sempadan pantai dalam pembangunan industri pariwisata, apa kendala dan upaya dalam mengatasi pelanggaran pemanfaatan dan penggunaan areal bebas sempadan pantai. Penelitian ini merupakan penelitian Normatif Empiris yaitu penelitian yang mengkaji hukum sebagai norma yang dapat dibuktikan dengan pelaksanaan atau penerapan di lapangan, sehingga penelitian ini disebut juga penelitian nondoktrinal, karena menggunakan peraturan perundang-undangan, teori hukum dan pendapat ahli hukum, yang dipadukan dengan kenyataan di lapangan berdasarkan data-data yang terkumpul dan informasiinformasi dalam kehidupan sosial di masyarakat. Pendekatan yang digunakan adalah pendekatan perundang-undangan (Statute Approach); pendekatan konsep (Conceptual Approach) dan pendekatan sosial (Social Approach). Teknik pengumpulan data dengan studi bahan hukum dan studi pengumpulan data lapangan. Setelah itu dilakukan pengolahan bahan hukum dengan menganalisanya melalui metode deskripsi, kemudian disusun secara sistematis dengan mencari unsur-unsur yang relefan dengan permasalahan yang dikaji, kemudian disusun menurut logika ilmiah dalam bentuk penulisan tesis. Berdasarkan hasil penelitian dapat disimpulkan bahwa: pemanfaatan dan penggunaan areal bebas sempadan pantai di Kabupaten Lobar NTB, $100 \%$ telah terjadi pelanggaran hukum Tata Ruang dan sampai saat ini masih terjadi "faktor pembiaran".
\end{abstract}

Kata Kunci: Pemanfaatan, Penggunaan, Sempadan Pantai, Pariwisata.

\section{ABSTRACT}

This study examines the use and utilization of coastal free areas in the development of tourism industry in Lobar-NTB. Issues of implementing the development, free of highway, the way of utilization and utilization of coastal free area in the development of tourism industry, what is the purpose and utilization of free shoreline facilities. This research is a normative empirical research 


\author{
[JATISWARA \\ gurnal Remu Hukum] [Vol. 32 No.1, Maret 2017]
}

that is a study that examines the law as a norm that can be proven by the application or application in the field, so this research is also called nondoktrinal research, because it uses legislation, legal theory and legal opinion, data based on collected data and information in social life in the community. The approach used is the statutory approach (Statute of Approach); conceptual approach (conceptual approach) and social approach (social approach). Technique data data and data. After that done the processing of legal materials by analyzing through the description method, then arranged systematically by searching for elements relefan elements with the problems studied, then arranged according to scientific logic in the form of thesis writing. Based on the result of the research, it can be concluded that the utilization and the use of coastal free area in Lobar NTB regency, 100\% has been negligence of spatial layout and until now there is still "omission factor".

Keywords: Utilization, Usage, Beach Border, Tourism.

\section{A. PENDAHULUAN}

Pemanfaatan dan penggunaan areal bebas sempadan pantai dalam pembangunan industri pariwisata telah terjadi pelanggaran Tata Ruang di beberapa wilayah tanah air, dan juga kasus serupa telah terjadi di Provinsi Nusa Tenggara Barat.

Pada tanggal 17 Oktober 2016, Dinas Pekerjaan Umum memberikan surat teguran kepada Badan Koordinasi Penataan Ruang Daerah (BKPRD) kabupaten/kota, dengan harapan masing-masing PEMDA juga menindak lanjuti teguran tersebut. "Kalau izin itu keluar dan melanggar garis sempadan pantai maka kita akan mengambil tindakan hukum," ujarnya. Teguran tersebut tentunya "berdasarkan data tim pokja pengendalian pemanfaatan ruang BKPRD Provinsi NTB, terdapat 48 (empat puluh delapan) indikasi pelanggaran tata ruang yang terjadi di Nusa Tenggara Barat, baik di Pulau Lombok dan Pulau Sum-bawa. Tapi jumlah personel dan terbatas-nya anggaran membuat tidak semua wila-yah bisa dipantau Dinas PU NTB". 1

Dalam PERDA Kabupaten Lombok Barat No.1 Tahun 2014 Lembaran Daerah Kabupaten Lombok Barat No.1 Tahun 2014 tentang Bangunan Gedung Pasal 22 ayat (3) menyatakan bahwa: "garis sempadan pantai dihitung dari titik pasang tertinggi, bervariasi sesuai dengan fungsi/aktifitas yang berada dipinggirannya,

${ }^{1}$ http://www.lombokpost.net/2016/10/18/catatpantai-milik-umum/ apabila tidak ditentukan lain, ditentukan dengan ketentuan" :

a. Kawasan permukiman, terdiri dari 2 (dua) tipe :

1. Bentuk pantai landai dengan gelombang kurang dari 2 (dua) meter, lebar sempadan pantai 30 75 meter; dan

2. Bentuk pantai landai dengan gelombang lebih dari 2 (dua) meter, lebar sempadan 50-100 meter.

b. Kawasan non permukiman, terdiri dari 4 (empat) tipe :

1. Bentuk pantai landai dengan gelombang kurang dari 2 (dua) meter, lebar sempadan 100-200 meter;

2. Bentuk pantai landai dengan gelombang lebih dari 2 (dua) meter, lebar sempadan 150-250 meter;

3. Bentuk pantai curam dengan gelombang kurang dari 2(dua) meter, lebar sempadan 200- 250 meter;dan

4. Bentuk pantai curam dengan gelombang lebih dari 2 (dua) meter, lebar sempadan 250- 300 meter $^{2}$. 
Dalam Pasal 33 ayat (3) UndangUndang Dasar Negara Republik Indonesia Tahun 1945 yang menyatakan :

"Bumi, air dan kekayaan alam yang terkandung di dalamnya dikuasai oleh Negara dan dipergunakan sebesar-besarnya untuk kemakmuran rakyat"3

Amanat Pasal 33 ayat (3) UndangUndang Dasar Negara Republik Indonesia Tahun 1945 tersebut, lebih lanjut diatur dengan Undang-Undang NO. 5 Tahun 1960 tentang Peraturan Dasar PokokPokok Agraria (Undang-Undang Pokok Agraria/ UUPA); Pasal 5 menyatakan bahwa: "Hukum agraria yang berlaku atas bumi, air dan ruang angkasa ialah hukum adat, sepanjang tidak bertentangan dengan kepentingan Nasional dan Negara". Dalam Pasal 6 dinyatakan bahwa: "semua hak atas tanah mempunyai fungsi sosial". Selanjutnya, dalam Pasal 14 yang secara tersirat mengatur perencanaan tata ruang seperti yang diamanatkan dalam ayat 2 yang berbunyi:

"Pemerintah Daerah mengatur persediaan, peruntukan dan penggunaan bumi, air serta ruang angkasa untuk daerahnya, sesuai dengan keadaan daerah masingmasing".

Berdasarkan PERPRES No.51 Tahun 2016 tentang Sempadan Pantai Pasal 27 menyatakan bahwa:

"Tentang batas sempadan pantai: adalah daratan sepanjang tepian pantai, yang lebarnya proporsional dengan bentuk dan kondisi fisik pantai, minimal 100 meter dari titik pasang tertinggi kearah darat".

Pemerintah daerah berdasarkan peraturan dan perundang-undangan yang berla$\mathrm{ku}$ dibebani dengan tugas kewenangan sebagai mana yang telah diatur dalam Pasal 7 Undang-Undang No 26 Tahun 2007 Tentang Penataan Ruang yang menyatakan:
1. Negara menyelenggarakan penataan ruang untuk sebesar-besar kemakmuran rakyat.

2. Dalam melaksanakan tugas sebagaimana dimaksud pada ayat 1 , Negara memberikan kewenangan penyelenggaraan penataan ruang kepada pemerintah dan pemerintah daerah.

3. Penyelenggaraan penataan ruang sebagaimana dimaksud pada ayat 2 dilakukan dengan tetap menghormati hak yang dimiliki orang sesuai dengan ketentuan peraturan

Berdasarkan latar belakang tersebut maka perumusan masalahnya sebagai berikut :

1. Bagaimana Pengaturan tentang Pemanfaatan dan Penggunaan areal bebas sempadan pantai?

2. Bagaimana Pelaksanaan Pemanfaatan dan Penggunaan areal bebas sempadan pantai dalam pembangunan industri pariwisata?.

3. Apa kendala dan upaya dalam mengatasi pelanggaran pemanfaata dan penggunaan areal bebas sempadan pantai ?

\section{B. METODE PENELITIAN}

\section{Jenis Penelitian}

Sesuai dengan judul dan rumusan masalah, maka jenis penelitian yang dipergunakan adalah penelitian hukum normatif - empiris.

\section{Pendekatan Masalah}

Dalam penelitian ini metode pendekatan yang digunakan adalah:

1. Pendekatan Perundang-undangan (Statute Approach).

2. Pendekatan Konsep (conceptual approach).

3. Pendekatan Sosiologis.

\section{Jenis Sumber Data / Bahan Hukum}

1. Kepustakaan

${ }^{3}$ Ibid hlm .4. 

dari:

Bahan hukum kepustakaan ini terdiri

a. Bahan Hukum Primer yaitu bahan hukum yang terdiri dari peraturan perundang-undangan :

1) Undang-Undang Dasar 1945.

2) Undang-Undang Nomor 5 Tahun 1960 Tentang Peraturan Dasar Pokok-Pokok Agraria.

3) Undang-Undang No.10 Tahun 2009 Tentang Kepariwisataan.

4) Undang-Undang Nomor 26 Tahun 2007 Tentang Penataan Ruang.

5) Peraturan Pemerintah Nomor 40 Tahun 1996 Tentang Hak Guna Usaha, Hak Guna Bangunan dan Hak Pakai Atas Tanah.

6) Peraturan Pemerintah No.16 Tahun 2004 Tentang Penataan Tanah.

7) Instruksi Presiden No. 9 Tahun 1969 Tentang Pedoman Pengembangan Kepariwisataan Nasional.

8) Perpres No. 51 tahun 2016 tentang Sempadan Pantai.

9) PERDA Kabupaten Lombok Barat No. 11 Tahun 2011 tentang RTRW.

10)PERDA Kabupaten Lombok Barat No.1 Tahun 2014 tentang Bangunan Gedung.

b. Bahan Hukum Sekunder yaitu bahan hukum yang terkait langsung dalam penelitian ini yang merupakan sebagai penunjang serta pelengkap dari bahan hukum primer yang terdiri dari pendapat-pendapat para ahli hukum dan doktrin, buku-buku referensi, teks atau tulisan-tulisan dan jurnal-jurnal hukum.

c. Bahan Hukum Tersier yaitu bahan hukum yang melengkapi dan memberikan penjelasan terhadap Bahan Hukum Primer dan Bahan Hukum
Sekunder seperti Kamus Hukum, Kamus Umum Bahasa Indo-nesia dan ensiklopedia.

2. Data Lapangan

\section{a. Data Primer}

Yaitu jenis data yang berhubungan langsung dengan data lapangan yang bersumber dari informan maupun responden pada lokasi penelitian.

b. Data Sekunder

Yaitu data yang bersumber dari dokument Instansi Pemerintah terkait dengan "Pemanfaatan dan Penggunaan Areal Bebas Sempadan Pantai Dalam Pembangunan Industri Pariwisata".

\section{Teknik Pengumpulan Data}

1. Studi Bahan Hukum yaitu dilakukan dengan teknik dokumen-tasi yaitu mengumpulkan bahan-bahan bacaan yang relevansinya sama dengan masalah yang diteliti.

2. Studi Lapangan yaitu teknik pengumpulan data dengan menggunakan metode wawancara terstruktur melalui situasi peran antara pribadi bertatap muka de-ngan mengajukan pertanyaan-pertanyaan yang telah dipersiapkan sebelumnya untuk memperoleh jawaban yang relevan dengan masalah penelitian kepada seorang responden yang mana di dalamnya termasuk quesioner, yaitu merupakan metode pengumpulan data dengan cara memberikan pertanyaan secara tertulis yang dijawab pula dengan cara tertulis yang diberikan kepada responden.

\section{Analisis Data atau Bahan Hukum}

Analisis bahan hukum dilakukan melalui metode deskripsi analitis terhadap berbagai ketentuan dan asasasas yang terkandung di dalam bahan hukum, kemudian disusun secara 
sistematis dengan mencari unsur-unsur yang relevan dengan permasalahan yang dikaji, kemudian disajikan menurut logika ilmiah dalam bentuk penulisan Tesis.

Dalam teknik penganalisaan data ini, peneliti menitik beratkan pada penganalisaan data yang diperoleh dari studi lapangan dan kepustakaan dengan cara menjelaskan atau melukiskan kenyataan-kenyataan atau keadaan obyek penelitian yang didapat dari hasil penelitian dilapangan, kemudian dikupas atau dibahas dengan teori-teori hukum sebagai pisau analisisnya sehubungan dengan permasalahan yang terkait dengan Pemanfaatan dan Penggunaan Areal Bebas Sempadan Pantai untuk dikaji Secara Yuridis, sehingga nanti akhirnya diperoleh simpulan hukum yang benar tentang sesuatu hal apa yang sesungguhnya terjadi dalam penelitian ini.

Dalam penelitian ini, peneliti juga telah menggunakan metode penyimpulan data dengan menggunakan metode atau kerangka berpikir deduktif yakni: jenis penyimpulan data dengan mengklarifikasi terlebih dahulu dari bentuk-bentuk yang bersifat umum ke sesuatu bentuk atau hal yang bersifat khusus.

\section{PEMBAHASAN}

6. Pengaturan Tentang Pemanfaatan dan Penggunaan Areal Bebas Sempadan Pantai

\section{a. Filososfi Areal Bebas Sempadan Pantai.}

Dari amanat Pembukaan Undang-Undang Dasar Negara Repulik Indonesia Tahun 1945 pada alinea IV yang berbunyi:

" Kemudian dari pada itu untuk membentuk suatu pemerintah Negara Indonesia yang melindungi segenap bangsa Indo- nesia dan seluruh tumpah darah Indonesia dan untuk mema-jukan kesejahteraan umum ...".

\section{b. Kepentingan Sosial.}

Dalam pasal 6 Undang-Undang Pokok Agraria yang menyatakan :

"Semua hak atas tanah mempunyai fungsi sosial". Penggunaan tanah harus disesuaikan dengan keadaannya dan sifat dari pada haknya hingga bermanfaat baik bagi kesejahteraan dan kebahagiaan yang mempunyainya maupun bermanfaat pula bagi masyarakat dan negara. Tetapi dalam pada itu ketentuan tersebut tidak berarti, bahwa kepentingan perseorangan akan terdesak sama sekali oleh kepentingan umum (masyarakat). UUPA memperhatikan pula kepentingan-kepentingan perseorangan. Kepentingan masyarakat dan kepentingan perseorangan haruslah saling mengimbangi, hingga pada akhirnya akan tercapailah tujuan pokok : kemakmuran, keadilan dan kebahagian bagi rakyat seluruhnya (Pasal 2 ayat 3). Berhubung dengan fungsi sosialnya maka adalah suatu hal yang sewajarnya bahwa tanah itu harus dipelihara baik-baik serta dicegah kerusakannya ${ }^{5}$.

\section{c. Kepentingan Masyarakat Umum.}

Areal Bebas Sempadan Pantai adalah, merupakan areal publik yang dapat dipergunakan oleh siapapun orangnya, artinya bahwa: setiap orang tanpa kecuali bebas dan leluasa dapat memanfaatkan areal tersebut dengan syarat, sepanjang pemanfaatan dan penggunaannya tidak berten-

4 Boedi harsono, Hukum Agraria Indonesia Himpunan Peraturan-Peraturan Hukum Tanah, Jakarta, Jambatan, Cet-15, 2002, hlm 33.

${ }^{5}$ Ibid hlm 7. 
tangan dengan peraturan dan perundang-undangan yang berlaku dalam hukum penataan ruang.

Tabel 1.

Nama Dan Letak Bangunan Dari Garis Sempadan Pantai Ke Arah Laut.

\begin{tabular}{|c|c|c|}
\hline No. & $\begin{array}{c}\text { Nama } \\
\text { Bangunan }\end{array}$ & $\begin{array}{l}\text { Letak Bangunan } \\
\text { dari Garis } \\
\text { Sempadan Pantai }\end{array}$ \\
\hline 1 & $\begin{array}{l}\text { Katamaran } \\
\text { Hotel }\end{array}$ & $\begin{array}{l}\text { maju } 11 \text { meter ke } \\
\text { arah laut }\end{array}$ \\
\hline 2 & & \\
\hline 3 & Holliday Resort & $\begin{array}{l}\text { maju 4,5 meter ke } \\
\text { arah laut }\end{array}$ \\
\hline 4 & Club Bahari & maju 4,5 meter ke \\
\hline 5 & Qunci & arah laut \\
\hline 6 & Resort & maju 4,5 meter ke \\
\hline 7 & Sudamala & \\
\hline 8 & Resort & maju 4,5 meter ke \\
\hline 9 & Puri Mas Resort & \\
\hline 10 & $\begin{array}{l}\text { HOTEL } \\
\text { MANGKRAK }\end{array}$ & $\begin{array}{l}\text { maju } 4 \text { meter ke } \\
\text { arah laut }\end{array}$ \\
\hline 12 & $\begin{array}{l}\text { Puri Saron } \\
\text { Resort }\end{array}$ & $\begin{array}{l}\text { berada di atas } \\
\text { Grs.Semp.Pantai }\end{array}$ \\
\hline 13 & Pacific Resort & $\begin{array}{l}\text { maju } 3 \text { meter ke } \\
\text { arah laut }\end{array}$ \\
\hline 14 & $\begin{array}{l}\text { Raja } \quad \text { Villas } \\
\text { Resort }\end{array}$ & $\begin{array}{l}\text { maju } 3 \text { meter ke } \\
\text { arah laut }\end{array}$ \\
\hline 16 & $\begin{array}{l}\text { Villa Pak Heru } \\
\text { Cina Batam }\end{array}$ & berada di atas \\
\hline 17 & Hotel Seraton & $\begin{array}{l}\text { Grs.Semp. Pantai } \\
\text { curam } 60 \text { derajat \& }\end{array}$ \\
\hline 10 & Lotus Bay & ada di ABSP \\
\hline 20 & $\begin{array}{l}\text { Vew/Complex } \\
\text { Psr. Seni }\end{array}$ & $\begin{array}{l}\text { maju } 6 \text { meter ke } \\
\text { arah laut }\end{array}$ \\
\hline 21 & Hotel Santosa & maju 2 meter ke \\
\hline 22 & $\begin{array}{l}\text { Kiila Senggigi } \\
\text { Beach }\end{array}$ & \\
\hline 23 & $\begin{array}{l}\text { Dharmarie Café } \\
\& \text { Baar }\end{array}$ & $\begin{array}{l}\text { berada di atas } \\
\text { Grs.Semp. Pantai }\end{array}$ \\
\hline 25 & Lina Hotel & $\begin{array}{l}\text { maju } 6 \text { meter ke } \\
\text { arah laut }\end{array}$ \\
\hline $\begin{array}{l}26 \\
27\end{array}$ & $\begin{array}{l}\text { The Paragon } \\
\text { Hotel }\end{array}$ & $\begin{array}{l}\text { maju } 2 \text { meter ke } \\
\text { arah laut }\end{array}$ \\
\hline 28 & Formeely Bar \& & maju 2 meter ke \\
\hline
\end{tabular}

\begin{tabular}{|c|c|c|}
\hline 29 & Restaurant & arah laut \\
\hline 30 & Aruna Hotel & maju 2,5 meter ke \\
\hline 31 & HOTEL STAIL & arah laut \\
\hline 32 & $\begin{array}{l}\text { LUMBUNG } \\
\text { SASAK }\end{array}$ & $\begin{array}{l}\text { maju } 2,5 \text { meter ke } \\
\text { arah laut }\end{array}$ \\
\hline 33 & Alberto Hotel & maju 2 meter ke \\
\hline 34 & Available Bar \& & arah laut \\
\hline 35 & Restaurant & maju 2,5 meter ke \\
\hline 36 & Sunset House \& & arah laut \\
\hline 37 & Restaurant & maju 2 meter ke \\
\hline 38 & $\begin{array}{l}\text { Batu Bolong } \\
\text { Hotel }\end{array}$ & maju 2 meter ke \\
\hline 39 & Transit Hotel & arah laut \\
\hline 41 & $\begin{array}{l}\text { JO-JO Beach } \\
\text { Bar }\end{array}$ & $\begin{array}{l}\text { maju } 2 \text { meter ke } \\
\text { arah laut }\end{array}$ \\
\hline 42 & $\begin{array}{l}\text { Indah Beach } \\
\text { Villa }\end{array}$ & $\begin{array}{l}\text { berada di atas } \\
\text { Grs.Semp. Pantai }\end{array}$ \\
\hline 44 & La Ita Beach & $\begin{array}{l}\text { berada di atas } \\
\text { Grs.Semp. Pantai }\end{array}$ \\
\hline 45 & $\begin{array}{l}\text { New Furama } \\
\text { Resort }\end{array}$ & $\begin{array}{l}\text { berada di atas } \\
\text { Grs.Semp. Pantai }\end{array}$ \\
\hline 47 & $\begin{array}{l}\text { The Chandi } \\
\text { Meru BT.Layar } \\
\text { Beach }\end{array}$ & $\begin{array}{l}\text { berada di atas } \\
\text { Grs.Semp. Pantai }\end{array}$ \\
\hline 49 & $\begin{array}{l}\text { Bintang } \\
\text { Senggigi Hotel }\end{array}$ & $\begin{array}{l}\text { berada di atas } \\
\text { Grs.Semp. Pantai }\end{array}$ \\
\hline 51 & $\begin{array}{l}\text { Rembulan Hotel } \\
\text { \& Restaurant }\end{array}$ & $\begin{array}{l}\text { maju } 2 \text { meter ke } \\
\text { arah laut }\end{array}$ \\
\hline 52 & $\begin{array}{l}\text { Halim Viber } \\
\text { Glas }\end{array}$ & $\begin{array}{l}\text { maju } 4,5 \text { meter ke } \\
\text { arah laut }\end{array}$ \\
\hline 54 & $\begin{array}{l}\text { Ocean Blue } \\
\text { Café }\end{array}$ & $\begin{array}{l}\text { maju } 2 \text { meter ke } \\
\text { arah laut }\end{array}$ \\
\hline & $\begin{array}{l}\text { Batu Layar } \\
\text { Hotel }\end{array}$ & $\begin{array}{l}\text { berada di atas } \\
\text { Grs.Semp. Pantai }\end{array}$ \\
\hline & $\begin{array}{l}\text { Atithi } \\
\text { Sanggraha } \\
\text { Hotel }\end{array}$ & $\begin{array}{l}\text { berada di atas } \\
\text { Grs.Semp. Pantai } \\
\text { berada di atas }\end{array}$ \\
\hline & Warung & Grs.Semp. Pantai \\
\hline & Menega & berada di atas \\
\hline & $\begin{array}{l}\text { Pakuna Beach } \\
\text { Hotel }\end{array}$ & $\begin{array}{l}\text { Grs.Semp. Pantai } \\
\text { berada di atas }\end{array}$ \\
\hline & $\begin{array}{l}\text { Lombok Beach } \\
\text { Villa }\end{array}$ & $\begin{array}{l}\text { Grs.Semp. Pantai } \\
\text { berada di atas }\end{array}$ \\
\hline & $\begin{array}{l}\text { HOTEL } \\
\text { TANPA NAMA }\end{array}$ & $\begin{array}{l}\text { Grs.Semp. Pantai } \\
\text { berada di atas }\end{array}$ \\
\hline
\end{tabular}




$\begin{array}{ll}\text { VP Melase } & \text { Grs.Semp. Pantai } \\ \text { The Jayakarta } & \text { berada di atas } \\ \text { Lombok Hotel } & \text { Grs.Semp. Pantai } \\ \text { ANONIM KIRI } & \text { berada di atas } \\ \text { CORAL PALM } & \text { Grs.Semp. Pantai } \\ \text { Coral Palm } & \text { berada di atas } \\ \text { Silver Fern } & \text { Grs.Semp. Pantai } \\ \text { Hotel \& } & \text { maju 1 meter ke } \\ \text { Restaurant } & \text { arah darat } \\ \text { Dolphin Lauge } & \text { maju 2 meter ke } \\ \text { Rias Refio } & \text { arah laut } \\ \text { The Place } & \text { maju 2,5 meter ke } \\ \text { Sekotong } & \text { arah laut } \\ \text { Yukie } & \text { maju 2,5 meter ke } \\ \text { Restaurant \& } & \text { arah laut } \\ \text { Bungallo } & \text { maju 2,5 meter ke } \\ \text { Krisna } & \text { arah laut } \\ \text { Restaurant \& } & \text { maju 2,5 meter ke } \\ \text { Bungallo } & \text { arah laut } \\ \text { PT.WBI } & \text { maju 3 meter ke } \\ \text { Sundancer } & \text { arah laut } \\ \text { Resort \& Café } & \text { maju 3 meter ke } \\ \text { Cocotinus Hotel } & \text { arah laut } \\ \text { Resort } & \text { maju 2 meter ke } \\ \text { Bola-Bola } & \text { arah laut } \\ \text { Paradis Hotel \& } & \text { berada di atas } \\ \text { Rstrnt. } & \text { Grs.Semp. Pantai } \\ \text { ANONIM } & \text { berada di atas } \\ \text { BUNGALLO } & \text { Grs.Semp. Pantai } \\ & \text { berada di atas } \\ \text { Grs.Semp. Pantai }\end{array}$

Sumber data : Hasil penelitian di lapangan

Untuk menggambarkan tentang adanya 3 (tiga) fariasi pelanggaran dalam pemanfaatan dan penggunaan areal bebas sempadan pantai dalam bisnis industri pariwisata di wilayah Kabupaten Lombok Barat Provinsi Nusa Tenggara Barat maka peneliti dapat menunjukan dengan Tabel 2 sebagai berikut:

\section{Tabel 2.}

Tiga Bentuk Tata Letak Bangunan Dari Garis Sempadan Pantai.

\begin{tabular}{ccc}
\hline $\begin{array}{c}\text { Maju 2 } \\
\text { meter } \\
\text { sampai 11 } \\
\text { meter ke } \\
\text { arah laut }\end{array}$ & $\begin{array}{c}\text { Maju hanya } \\
\text { 1 meter ke } \\
\text { arah darat }\end{array}$ & $\begin{array}{c}\text { Berada pada } \\
\text { garis } \\
\text { sempadan } \\
\text { pantai }\end{array}$ \\
\hline $\begin{array}{c}\text { 31 bangunan } \\
(\mathbf{5 7 , 4 1 \%})\end{array}$ & $\begin{array}{c}1 \text { bangunan } \\
(1,85 \%)\end{array}$ & $\begin{array}{c}22 \text { bangunan } \\
(40,74 \%)\end{array}$ \\
\hline
\end{tabular}

Sumber Data : Hasil pengamatan di lapangan

\section{d. Pengaturan Penggunaan Areal Bebas Sempadan Pantai Berdasarkan Undang-Undang :}

a. Undang-Undang Pokok Agraria.

Sebanyak 58 (lima puluh delapan) Pasal yang terdapat dalam Undang-Undang Pokok Agraria/ UUPA, tidak ada Pasal yang secara tekstual dan secara gamblang mengatur tentang areal bebas sempadan pantai, namun bila dicermati secara mendalam bahwa dalam UUPA tersebut telah mengantisipasinya dengan pasal yang dapat kita temui di dalam Pasal 6 yang menyatakan: "Semua hak atas tanah mempunyai fungsi sosial" 6 dan dalam Pasal 7 UUPA menyatakan: "Untuk tidak merugikan kepentingan umum maka pemilikan dan penguasaan tanah yang melampaui batas tidak diperkenankan"

b. Undang-Undang Penataan Ruang.

Dalam undang-undang No.26 Tahun 2007 tentang Penataan Ruang, juga tidak terdapat Pasal yang mengatur tentang Wilayah Sempadan Pantai yang dapat dijadikan acuan dalam menetapkan Areal Bebas Sempadan Pantai khususnya. Relevansi UndangUndang tersebut dengan materi penelitian ini, penulis memandang dari perspektif adanya kata "pemanfaatan ruang harus berdasarkan izin dan memberikan akses demi kepentingan umum" dalam Pasal 61, adanya

${ }^{6}$ Ibid. hlm 7 
sanksi Administratif dalam Pasal 62 dan Pasal 63 serta Ketentuan Pidana yang terdapat pada Pasal 73 sebagai berikut:

Ketentuan pidana sebagaimana yang telah diatur dalam Pasal 69 sampai Pasal 72 diancam pidana 1 (satu) tahun sampai 8 (delapan) tahun dan denda paling banyak Rp. 100.000.000,00 (seratus juta rupiah) samapai Rp. 5.000.000.000,00 (lima miliar rupiah).

Pasal 73.

1) Setiap pejabat pemerintah yang berwenang yang menerbitkan izin tidak sesuai dengan rencana tata ruang, sebagaimana yang dimaksud dalam Pasal 37 ayat 7 (setiap pejabat pemerintah yang berwenang menerbitkan izin pemanfaatan ruang dilarang memberikan izin yang tidak sesuai dengan rencana tata ruang), dipidana dengan pidana penjara paling lama lima tahun dan denda paling banyak Rp. 500.000.000,00 (limaratus juta rupiah).

2) Selain sanksi pidana sebagaimana dimaksud pada ayat 1 (satu) pelaku dapat dikenai pidana tambahan berupa pemberhentian secara tidak hormat dari jabatannya.

c. Undang-Undang No.27 tahun 2007 tentang Pengelolaan Wilayah Pesisir dan Pulau-pulau Kecil.

menetapkan:

Dalam Pasal 1 butir (21) telah

"Sempadan Pantai adalah daratan sepanjang tepian pantai, yang lebarnya proporsional dengan bentuk dan kondisi fisik pantai, minimal 100 meter dari titik pasang tertinggi kearah darat". 7 d. Peraturan Menteri Negara Agraria/ Kepala Badan Pertanahan Nasional No. 2 Tahun 1999 Tentang Izin Lokasi.

e. Pengaturan Penggunaan Areal Bebas Sempadan Pantai Berdasarkan PERPRES.

Berdasarkan PERPRES No.51 Tahun 2016 tentang Sempadan Pantai dalam Pasal 27 menetapkan:

"Tentang batas sempadan pantai: adalah daratan sepanjang tepian pantai, yang lebarnya proporsional dengan bentuk dan kondisi fisik pantai, minimal 100 meter dari titik pasang tertinggi kearah darat".

f. Pengaturan Penggunaan Areal Bebas Sempadan Pantai Berdasarkan PERDA:

1) PERDA Provinsi NTB No.3 Tahun 2010 tentang Tata Ruang Wilayah Provinsi. Lembaran Daerah No. 26 Tahun 2010.

g. PERDA Kabupaten Lombok Barat No.1 Tahun 2014 tentang Tata Ruang Wilayah Kabupaten, Lembaran Daerah No. 106 Tahun 2014, tidak ada satu pasalpun yang mengatur Areal Bebas Sempadan Pantai, kecuali PERDA Kabupaten Lombok Barat No.1 Tahun 2013 tentang Pengelolaan Wilayah Pesisir dan Pulau-Pulau Kecil telah diatur dalam Pasal 1 butir 32 (tiga puluh dua) menyatakan bahwa:

"Sempadan Pantai adalah dataran sepanjang tepian yang lebarnya diukur sejauh 30 (tiga puluh) meter sampai dengan 250 (dua ratus lima puluh) meter dari pasang tertinggi secara proporsional dengan mengacu pada karakteristik topografi, biofisik, hidro oceanografi pesisir, kebutuhan ekonomi

${ }^{7}$ Undang-Undang No.27 Tahun 2007 tentang Pengelolaan Wilayah Pesisir dan Pulau-Pulau Kecil. 
dan budaya". 8

PERDA Lombok Barat No. 1 Tahun 2013 tersebut bila peneliti mencermainya secara saksama, maka tidaklah berlebihan bila penulis menyatakan bahwa PERDA tersebut adalah PERDA pesanan dan masuk angin. Hal ini peneliti dapat buktikan berdasarkan data, fakta dan kenyataan di lapangan yang telah menunjukan bahwa: " telah terjadi faktor pembiaran selama 10 (sepuluh) tahun yaitu sejak lahirnya Undang-Undang No.26 Tahun 2007 tentang Penataan Ruang di dalam Pasal 73 telah mengatur tentang sanksi pidana namun terbukti sampai saat penulis merampungkan penulisan TESIS ini, penulis belum pernah menemukan adanya Pejabat PEMDA LOBAR maupun Investor Industri Pariwisata yang dihukum pidana karena Kejahatan pemberian izin membangun di atas Areal Bebas Sempadan Pantai. Semua unit bangunan yang berbatasan dengan tepian pantai, telah melewati garis sempadan pantai 2 (dua) meter sampai 11 (sebelas) meter ke arah laut namun anehnya Negara yang benama Negara Republik Indonesia ini, hal-hal seperti itu tidak pernah dihukum pidana, sehingga patu dipertanyakan secara hukum.

Pemanfaatan dan penggunaan areal bebas sempadan pantai berdasarkan PERDA Kabupaten Lombok Barat yang ada sekarang bila dikaji dari Perspektif Hirarki Hukum dan Azas Umum dalam ilmu hukum, adalah bertentangan dengan azas yang menyatakan bahwa: Peraturan dan perundangan yang ada di bawahnya tidak dapat mengalahkan peraturan dan perundangan yang berada di atasnya "(Lex Superior de Rogat Legi Inferiori)", oleh sebab itu penulis berpendapat bahwa: seharusnya PERDA

8 PERDA Kabupaten Lombok Barat tentang Pengelolaan Wilayah Pesisir dan Pulau-Pulau Kecil, No.1 Tahun 2013 tersebut harus segera dicabut dan dinyatakan batal demi hukum dan bukan batal karena hukum.

Sehubungan dengan tidak jelasnya hukum mengatur ruang pesisir atau areal bebas sempadan pantai sehingga menimbulkan "grey area", maka diperlukan kehadiran negara dengan kewenangannya untuk mengatur. Terkait dengan kewenangan negara, ajaran pokok Thomas Hobbes menjastifikasi kewenangan negara guna menciptakan keamanan dan ketertiban.

Keamanan dan ketertiban akan terwujud jika ada kekuasaan yang superior dan berdaulat yang dapat memaksakan kekuasaannya secara absolut dan dapat menuntut ketaatan seluruh warga negara tanpa penawaran. Postulat Hobbes, yang menyatakan kekuasaan yang berdaulat inilah sesungguhnya menjadi sumber hukum sekaligus satu-satunya yang berkuasa untuk mengubahnya. ${ }^{9}$

Hobbes mengandaikan negara seperti 'Leviathan', ular raksasa laut yang menakutkan sehingga dipatuhi oleh warga masyarakat. Menurut Hobbes, harus ada Leviathan yang bisa menentukan apa yang baik dan apa yang buruk dari manusia. Leviathan sang protagonis, mesias, penyelamat, yang memberi penerangan, ide-ide, dan cahaya. Dalam konteks Hobbesian kepatuhan didasarkan pada rasa takut, negara/pemerintah dapat mengklaim wewenang karena ada daya-sanksi di dalamnya. Hukum lantas menjadi bentuk perintah dari pemerintah, dan manusia mematuhinya karena ada sanksi atas ketidak patuhan atas hukum tersebut.

Pemanfaatan dan penggunaan areal bebas sempadan pantai dalam industri pariwisata yang diatur dengan PERDA LOBAR yang ada selama ini

9 Op. Cit. Thomas Hobbes, Leviathan (Diedit oleh Edwin Curley). 
dan bila dikaji atau dianalisa dengan teori hukum dari Hobbes, harus ada " Leviatan," ular raksasa laut yang menakutkan, namun dalam penerapan di lapangan menurut pendapat penulis bahwa PERDA LOBAR yang ada sekarang adalah "Leviatan" yang telah berubah menjadi "Ular Timah" yang bentuknya menyerupai cacing tanah berwarna perak, dan sama sekali tidak menakutkan sehingga tidak perlu dipatuhi karena sudah tidak lagi menyeramkan dan tidak memiliki kewibawan yang layak untuk dipatuhi dan ditaati, demikianlah ibaratnya PERDA LOBAR yang ada sekarang, sehingga dengan mudah untuk dilanggar oleh pembisnis industri pariwisata, karena PERDA LOBAR sejatinya bertentangan dengan Undang-Undang yang telah ada di atas sebelumnya.

Hukum merupakan perintah dari mereka yang memegang kekuasaan tertinggi atau dari pemegang kedaulatan. Austin menganggap hukum sebagai suatu sistem yang logis, tetap dan bersifat tertutup. Menurutnya hukum yang sebenarnya mengandung empat unsur yaitu; perintah, kedaulatan, kewajiban, dan sanksi.

7. Pelaksanaan Pemanfaatan Dan Penggunaan Areal Bebas Sempadan Pantai Dalam Pembangunan Industri Pariwisata

\section{a. Dasar Pemanfaatan dan Penggunaan Areal Bebas Sempadan Pantai.}

Tabel 3.

Legalitas bangunan berdasarkan izin.

\begin{tabular}{cc}
\hline $\begin{array}{c}\text { Bangunan Legal } \\
\text { (Ada izin) }\end{array}$ & $\begin{array}{c}\text { Bangunan Ilegal } \\
\text { (Tanpa izin) }\end{array}$ \\
\hline $\begin{array}{c}\mathbf{4 8} \text { unit } \\
\text { bangunan }(\mathbf{8 8 , 8 9 \% )})\end{array}$ & $\begin{array}{c}6 \text { unit bangunan } \\
(11,11 \%)\end{array}$ \\
\hline
\end{tabular}
lapangan

Sumber Data : Hasil pengamatan di

a. Bangunan Legal karena memiliki Izin.
Bahwa adanya 48 (empat puluh delapan) atau 88,89\% unit bangunan legal yang memiliki izin membangun dari pemerintah Kabupaten Lombok Barat, sesungguhnya tidak ada bedanya dengan 6 (enam) unit bangunan ilegal $(11,11 \%)$ yang tanpa izin.

b. Bangunan Ilegal karena Tanpa Izin.

Keberadaan 6 (enam) unit bangunan atau $11,11 \%$ unit bangunan tanpa izin, dalam perspektif hukum sesungguhnya adalah sama posisinya dengan $88,89 \%$ unit bangunan yang telah mendapatkan izin dari pemda lobar.

Pelaksanaan Pemanfaatan Areal Bebas Sempadan Pantai Oleh Pelaku Bisnis Industri Pariwisata

a) Memanfaatkan Areal Bebas Sempadan Pantai sesuai dengan keberadaan izin.

b) Memanfaatkan Areal Bebas Sempadan Pantai dengan menambah sendiri di luar izin.

c) Memanfaatkan Areal Bebas Sempadan Pantai tanpa izin.

Dampak Dari Pemanfaatan dan Penggunaan Areal Bebas Sempadan Pantai Terhadap Masyarakat.

a. Dampak Sosial.

b. Dampak Ekonomi.

c. Dampak Budaya.

Dampak Dari Pemanfaatan dan Penggunaan Areal Bebas Sempadan Pantai Terhadap Ekosistim Wilayah Sempadan.

a. Ekosistim wilayah Sempadan menjadi tidak ASRI dan lestari.

b. Ekosistem wilayah Sempadan menjadi amburadul dan kumuh.

c. Ekosistem wilayah Sempadan menjadi kehilangan daya pikatnya.

Kendala dan Upaya dalam Mengatasi Pelanggaran Pemanfaatan Areal Bebas Sempadan Pantai 
1. Kendala-Kendala.

a. Kendala Yuridis

b. Kendala Sistematik.

c. Kendala Sosialogis.

d. Kendala budaya NEPOTISME .

e. Kendala diskriminasi hukum.

f. Kendala memanjakan turis/ wisatawan asing dengan perlakuan istimewa.

2. Upaya Mengatasi Pelanggaran Rencana Tata Ruang Wilayah (RTRW) Areal Bebas Sempadan Pantai.

Dalam upaya mengatasi kendala RTRW tidak terlepas dari faktor-faktor non yuridis seperti:

a. Investor Pebisnis Industri Pariwisata yang hanya beroreantasi pada keuntungan belaka, tanpa peduli dengan Areal Bebas Sempadan Pantai sebagai ruang publik.

b. Budaya masa bodoh dan proses pembodohan tentang RTRW terhadap masyarakat oleh pemerintah secara sistematik.

c. Budaya diskriminasi dalam penegakan hukum oleh instansi pemerintah terkait serta budaya KKN yang masih melekat.

d. Budaya gagal paham dan ketersediaan SDM dari aparat pemerintah tentang Hukum Tata Ruang sehubungan dengan Areal Bebas Sempadan Pantai yang masih rendah.

e. Dissinkronisasi peraturan dan perundang-undangan yang ada, yaitu aturan yang dibawah menyalahi aturan yang diatasnya sehingga bertentangan dengan hirarki hukum yang berlaku.

f. Disharmonisasi dari dinas perizinan terpadu atau antar instansi yang mengeluarkan ijin seperti:
1) Badan Pertanahan Nasional (BPN) dan tata ruang

2) Dinas Pekerjaan Umum (PU)

3) Dinas lingkungan hidup

4) Badan Perencanaan Pembangunan Daerah (BAPPEDA)

Kenyataan-kenyataan pelanggaran yang terjadi diperparah oleh beberapa hal sebagai berikut:

1. Sertipikat Tanah Hak Milik yang diterbitkan pada wilayah yang mencaplok Areal Bebas Sempadan Pantai, berdasarkan informasi dari Badan pertanahan dan Agraria Kabupaten Lombok Barat/ LOBAR, bawhwa 100\% unit bangunan yang berada di Wilayah Kecamatan Batu Layar (daerah Senggigi sekitarnya) dan $75 \%$ unit bangunan yang berada di Wilayah Kecamatam Sekotong telah dibangun di atas TANAH yang sudah BERSERTIPIKAT HAK MILIK. Artinya dalam hal ini pihak BPN LOBAR ikut serta atau turut membantu dalam pelanggaran hukum, karena mensertipikatkan tanah milik umum men-jadi milik pribadi.

2. Lahirnya Sertipikat Tanah Hak Milik Ilegal, dengan pemalsuan data fisik dan data yuridis berupa SPPT tanah yang berlokasi di tempat lain. Iformasi Sertipikat Ilegal ini terungkap ketika penulis mewawancarai salah seorang KABAG di lingkungan Kantor Dinas Pariwisata LOBAR Giri Menang.

3. Mendirikan bangunan yang berada pada tebing curam di atas garis areal bebas sempadan pantai dengan kemiringan lebih dari 40 derajat kearah laut. Kejadian ini dapat disaksikan di wilayah sebelah utara KATAMARAN HOTEL dan di wilayah sebelah utara HOTEL SERATON Senggigi Kecamatan Batu Layar LOBAR. 
4. Mendirikan bangunan yang melanggar areal batas sempadan pantai (kurang dari 100 meter) dari titik pasang tertinggi air laut kearah darat. Dapat dilihat pada Tabel 1.

5. Mendirikan bangunan pada areal reklamasi 2 (dua) meter sampai 11 (sebelas) meter masuk kearah laut, akibat telah terjalin SIMBIOSIS MUTUALISME antara Penguasa dengan Pengusaha. Dapat dilihat pada Tabel 1 .

6. Disharmoni antar pejabat dalam memberikan izin membangun karena dipicu oleh egosentris lintas sektoral dan mengejar bayaran retribusi yang berorientasi pada pemasukan Pendapatan Asli Daerah (PAD). Dapat dilihat pada Tabel 1.

7. Peraturan dan perundangan yang berlaku telah dikalahkan oleh infestasi bisnis pariwisata. Artinya Penguasa dikalahkan oleh Pengusaha. Dapat dilihat pada Tabel 1.

8. Fungsi kontrol dari pemerintah menjadi lemah karena tekanan ekonomi, politik dan kepentingan partai yang sedang berkuasa. Dapat dilihat pada Tabel 1.

9. Masih adanya budaya Asal Bapak Senang (ABS) dikalangan pejabat yang memberikan izin membangun. Dapat dilihar berdasarkan wawancara penulis dengan pejabat di lingkungan Pemerinhan LOBAR di halaman sebelumnya.

10. Masih kentalnya budaya Korupsi Kolusi dan Nepotisme (KKN) di kalangan pejabat pemerintah terkait dalam bidang Industri Pariwisata di lingkungan Pemerintah Kabupaten LOBAR. Dapat disaksikan dengan kenyataan yang ada, bahwa: Para Pelanggar Areal Babas Sempadan Pantai sampai saat ini, masih aman-aman saja dan aparat pejabat tidak ada yang di- penjara dan dipecat dari jabatannya karena mengeberikan yang terlarang.

11. Adanya budaya memanjakan turis/ tamu hotel secara berlebih-lebihan sehingga areal bebas sempadan pantai telah diprivatisasi oleh pembisnis industri pariwisata. Perlakun yang berlebih-lebihan tersebut dapat dibuktikan di Hotel COCOTINUS Sekotong Tengah, Hotel KIILA SENGGIGI BEACH di Pantai Senggigi, Hotel SERATON di Pantai Senggigi, Hotel CHANDI MERU BEACH di Pantai Batu Layar dan Hotel JAYAKARTA LOMBOK di Pantai Batu Layar.

Dari sejumlah bentuk dan fariasi pelanggaran Areal Bebas Sempadan Pantai tersebut, bagi penulis memandang sebagai suatu pertanda kebenaran dari pendapat seorang ahli hukum, khususnya yang bernama Hobbes, penulis sepaham dengan pandangan beliau yang beranggapan bahwa manusia itu sejatinya jahat, maka wewenang dan hukum dibutuhkan, namun dalam pelaksanaan pembutan PERDA LOBAR, tentang kewenangan Pemerintah untuk membuat PERDA yang berdampak pada kesejahteraan masyarakat umum belum tercapai.

Undang-Undang Penataan Ruang sebagai payung huku Nasional yang diharapakan akan dijadikan acuan bagi Daerah-Daerah di Seluruh Indonesia di dalam Rencana Tata Ruang Wilayah/ RTRW, ternyata tidak terdapat satupun Pasal yang secara tegas mengatur Areal Bebas Sempadan Pantai.

\section{SIMPULAN DAN SARAN}

\section{Simpulan}

$\begin{array}{lrrrr} & \text { Pertama: } & \text { Bahwa PERDA } & \text { Provinsi } \\ \text { NTB } & \text { No.3 } & \text { Tahun } & 2010 \quad \text { tidak }\end{array}$ mengakomodir tentang aturan Pemanfaatan dan Penggunaan Areal Bebas Sempadan Pantai, sedangkan PERDA LOBAR No. 1 Tahun 2013 telah melangar Hierarki Hukum sehingga menimbulkan kontradiksi antar norma karena bertentangan dengan 
Undang-Undang No. 27 Tahun 2007 Pasal (1) butir (21), walaupun sudah dirubah dengan Undang-Undang No.1 Tahun 2014 namun pada Pasal (1) butir (21) tidak mengalami perubahan, artinya PERDA Kabupaten LOBAR cacat YURIDIS .

Kedua: Bahwa pembangunan industri pariwisata di Kabupaten LOBAR, $100 \%$ telah melanggar Tata Ruang dalam Pemanfaatan dan Penggunaan Areal Bebas Sempadan Pantai, karena seluruh unit bangunan telah dibangun dengan posisi bangunan yang mengambil 99 (Sembilan puluh Sembilan) meter sampai 100 (seratus) meter Areal Bebas Sempadan Pantai, malah maju 2 (dua) meter sampai 11 (sebelas) meter ke arah laut dari garis sempadan pantai, yang oleh pemerintah Kabupaten LOBAR telah terjadi "faktor pembiaran".

Ketiga: Bahwa Kendala dalam upaya mengatasi pelanggaran pemanfaatan dan penggunaan areal bebas sempadan pantai di Kabupaten LOBAR adalah : Adanya penerbitan sertipikat tanah hak milik dengan pemalsuan data fisik dan data yuridis; izin membangun pada tebing curam dengan kemiringan lebih dari 40 derajat kearah laut; adanya SIMBIOSIS MUTUALISME antara Penguasa dengan Pengusaha; disharmoni antar pejabat dalam memberikan izin membangun; adanya factor pembiaran terhadap pelanggaran dari pemerintah yang sedang berkuasa; dissinkronisasi antara PERDA Kabupaten LOBAR dengan Peraturan dan Perundangan yang telah ada di atasnya; masih adanya budaya Asal Bapak Senang (ABS) dikalangan pejabat yang memberikan izin membangun; masih kentalnya budaya Korupsi Kolusi dan Nepotisme (KKN) di kalangan pejabat pemerintah; adanya budaya memanjakan turis/ tamu hotel secara berlebih-lebihan sehingga areal bebas sempadan pantai telah diprivatisasi oleh pembisnis industri pariwisata.

\section{Saran dan Rekomendasi}

Pertama : Tentang PERDA Provinsi Nusa Tenggara Barat No. 3 Tahun 2010 sebaiknya direvisi dan PERDA Kabupaten Lombok Barat No. 1 tahun 2013 untuk segera dicabut lalu direvisi untuk disesuaikan dengan Undang-Undang No. 27 tahun 2007 atau disesuaikan dengan UndanUndang No.1 tahun 2014 yang substansi hukumnya harus mengacu pada pasal 1 butir (21).

Kedua : Tentang sejulah 54 (lima puluh empat) unit bangunan yang telah melanggar areal bebas sepadan panatai, agar secepatnya ditindak tegas dengan menjatuhkan sanksi administrasi maupun sanksi pidana sebagimana yang telah diatur dalam Undang-Undang No. 26 tahun 2007.

Ketiga : Budaya ABS dan KKN yang masih melekat pada aparat pemerintah Kabupaten LOBAR yang terkait dengan pemberian izin membangun dalam Pemanfaatan dan Penggunaan Areal Bebas Sempadan Pantai, agar segera ditinggalkan.

\section{DAFTAR PUSTAKA}

\section{Buku-Buku}

Arba Muhammad Haji, Hukum Tata Ruang dan Tata Guna Tanah (Prinsip-Prinsip Hukum Perencanaan Penataan Ruang dan Penatagunaan Tanah), (Mataram: Pustaka Bangsa, 2014).

Achmad Sodiki dan Yanis Maladi, Politik Hukum Agraria, (Yogyakarta: Mahkota Kata Yogyakarta, 2009).

Bambang Sugono, Metodologi Penelitian Hukum, (Jakarta: PT. Raja GrafindoPersada, 2001),

Basuki Antariksa, Kebijakan Pembangunan Kepariwisataan, Pengembangan

Kepariwisataan yang Berkelanjutan dan 
Perlindungan Kekayaan

Intelektual, (Malang: Intrans

Publishing, 2016).

George Ritzer dan Douglas J. Goodman, "Teori Sosiologi Modern (Modern Sociological Theory)", Diterjemahkan oleh Alimandan, Jakarta: Prenada, 2007.

Hutagalung Arie Sukanti dan Gunawan Markus,

Kewenangan Pemerintah di Bidang Pertanahan, (Jakarta: PT. RAJAGRAFINDO PERSADA, 2009).

Indonesia, Kamus Besar Bahasa, Departeman Pendidikan dan Kebudayaan, (Jakarta: Balai Pustaka, 1989).

Lawrence M. Friedman, SISTIM HUKUM Perspektif Ilmu Sosial (THE LEGAL SYSTEM Asosial Science Perspektif), (Jakarta: Nusamedia, ....)

Mukti Fajar ND dan Yulianto Achmad, "Dualisme Penelitian Hukum Normatif dan Hukum Empiris",(Yogyakarta: Pustaka Pelajar, 2010).

Otje Salman H.R. dan Susanto Anthon F., Teori Hukum Mengingat, Mengumpukan dan Membuka Kembali,(Bandung: PT. Refika Aditama, 2008).

Sahnan, Menguak Tabir SENGKETA PERTANAHAN Di Kawasan Pariwisata, (Jakarta: Bania Publisting, 2014).

$\begin{array}{ll} & \text { Indonesia, (Makum } \\ & \text { Press, 2016) } \\ \text { Salim } & \text { HS, Penerapan Teoria Hukum } \\ & \text { Pada Penelitian Disertasi Dan } \\ & \text { Tesis, (Jakarta: Fajar } \\ & \text { Interpratama Mandiri,2015). }\end{array}$

Team MIH Publishing, “Buku
Pedoman Penyelenggaraan Akademik, Penulisan Tesis dan Jurnal Ilmiah", (Mataram: Magister Ilmu Hukum UNRAM, 2014).

Zainal Asikin Haji, Mengenal Filsafat Hukum, (Bandung: Pustaka Reka Cipta, 2014).

\section{Undang-Undang}
Undang-Undang Dasar Negara Republik Indonesia Tahun 1945.

Undang-Undang Nomor 5 Tahun 1960 Tentang Peraturan Dasar Poko-pokok Agraria(UUPA). (L.N RI 1960-No.104).

Undang-Udang No. 26 tahun 2007 tentang Penataan Ruang. (L.N RI 2007-No.68).

Undang-Undang No.10 Tahun 2009 Tentang Kepariwisataan. (L.N RI 2009-No.11)

Peraturan Pemerintah Republik Indonesia No. 40 Tahun 1996 Tentang Hak Guna Usaha, Hak Guna Bangunan dan Hak Pakai Atas Tanah. (L.N RI 1996No.,,,)

Peraturan Pemerintah Republik Indonesia No.16 Tahun 2004 Tentang Penataan Tanah. (L.N RI 2004-No.,,,)

Peraturan Pemerir Republik Indonesia No.iJ I anun 2010 Tentang Penyelenggaraan Penataan Ruang. (L.N RI 2010-No.21).

Perpres RI No. 9 Tahun 1969 Tentang Pedoman Pengembangan Kepariwisataan Nasional. (L.N RI 1969-No.,,,)

Perpres RI No.56 Tahun 2014 Tentang Rencana Tata Ruang Kepulauan Nusa Tenggara. (L.N RI 2014-No.135) 
[Vol. 32 No.1, Maret 2017

ISWARA

'enu Hukeum]

Perpres RI No. 51 tahun 2016 tentang

http://tentangpariwisata.blogsp

Sempadan Pantai. (L.N RI 2016-No.,,,)

ot.com

\section{Internet.}

Internet Https://brainly. Co. id. 11 tahun 2011 tentang Rencana Tata Ruang Wilayah.

Internet

http://Www.Lombokpost.Net/20 16/10/18/Catat-Pantai-MilikUmum/://Brainly. Co. id.

No.1 tahun 2014 tentang Bangunan Gedung.

\section{Artikel.}

Yani Adriani, "Defenisi Pariwisata dari Berbagai Sudut Pandang",Makalah dalam

http://filzaatikaa.blogspot.co.id/2012/0 3/penegakan-hukum.html

chttp://dedeandreas.blogspot.co.id/2015/03 Iteori-sistem-hukum-lawrence-mfriedman.html 